\title{
Intracranial epidermoid cyst in a cat
}

\section{Renata Dalcol Mazaro ${ }^{*}$ (D) Douglas Miotto Lorenzetti ${ }^{1}$ (i) Milena Carolina Paz $^{2}$ (i) Rafael Almeida Fighera ${ }^{1}$ (D)}

1'Departamento de Patologia, Universidade Federal de Santa Maria (UFSM), 97105-900, Santa Maria, RS, Brasil. E-mail: renatamazarovet@gmail.com. "Corresponding author.

${ }^{2}$ Departamento de Medicina Veterinária, Universidade Federal de Santa Maria (UFSM), Santa Maria, RS, Brasil.

ABSTRACT: Epidermoid cysts, also known as epidermal and keratin cysts, or congenital cholesteatomas are benign congenital nonneoplastic tumors, rarely observed in the brain of humans and some animal species (dogs, horses, mice, and rats). Histologically, they are composed of laminated, concentrically arranged keratin surrounded by a thin layer of stratified squamous epithelium. We describe a case of intracranial epidermoid cyst in a 6-year-old mixed-breed male cat in southern Brazil. The patient presented central vestibular syndrome. Given the poor prognosis and the fact that it belonged to a shelter with many dogs and cats, the owner requested euthanasia, and a thorough postmortem examination was conducted immediately after death. The definitive diagnosis was based on histopathological findings. To the best of our knowledge, this is the first report of an intracranial epidermoid cyst in a cat.

Key words: epidermal cyst, intracranial cyst, congenital cholesteatoma, cerebellopontine angle, cat.

Cisto epidermoide intracraniano em um gato

RESUMO: Cisto epidermoide, também denominado cisto epidermal, cisto de queratina ou colesteatoma congênito é um tumor não neoplásico, benigno e congênito raramente encontrado no encéfalo de humanos e de algumas poucas espécies animais (cães, equinos, camundongos e ratos). Histologicamente, esse tumor é composto por queratina laminada concentricamente arranjada e circundada por uma fina parede de epitélio escamoso estratificado. Descreve-se um caso de cisto epidermoide intracraniano em um gato, macho, sem raça definida, de seis anos de idade, no sul do Brasil. O paciente foi encaminhado para atendimento veterinário por apresentar sinais de síndrome vestibular central. Devido ao mau prognóstico e por pertencer a um abrigo com muitos cães e gatos, o proprietário optou pela eutanásia e o paciente foi encaminhado para a realização de necropsia. O diagnóstico definitivo foi baseado nos achados histopatológicos. Pelo conhecimento dos autores, este é o primeiro relato de um cisto epidermoide intracraniano em um gato.

Palavras-chave: cisto epidermal, cisto intracraniano, colesteatoma congênito, ângulo pontinocerebelar, gato.

Epidermoid cysts, also known as epidermal keratin, infundibular, and epidermal inclusion cysts, or congenital cholesteatomas (LLOYD, 1964; TOGLIA et al., 1965; GOLDSCHMIDT \& SCHOFER, 1992; GROSS et al., 2005; NAGASAWA et al., 2011), are non-neoplastic tumors common in the skin of dogs and cats, but are occasionally observed in internal organs (GOLDSCHMIDT \& SCHOFER, 1992; MACKILLOP et al., 2006; NIEDERHÄUSER et al., 2015). Intracranial cysts arise from cutaneous epithelial cells trapped in the brain during embryonic life (TOGLIA et al., 1965; SMIRNIOTOPOULOS \& CHIECHI, 1995; NAGASAWA et al., 2011). This happens when the ectoderm fails to separate completely from the neuroectoderm during neural tube closure (TOGLIA et al., 1965; SMIRNIOTOPOULOS \& CHIECHI, 1995).

Intracranial epidermoid cysts have rarely been described in dogs (KORNEGAY \& GORGACZ, 1982; MACKILLOP et al., 2006), horses (PETERS et al., 2003), humans (NAGASAWA et al., 2011), mice (CANTILE \& YOUSSEF, 2016), and rats (SUGIMOTO et al., 1994). However, there are still no reports of this condition in the feline medical literature, only sporadic descriptions in textbooks (CANTILE \& YOUSSEF, 2016), and reports of extracutaneous presentation involving the intestine, larynx, or lungs (MILLI \& HAZIROGLU, 1990; 
NIEDERHÄUSER et al., 2015; SILVA et al., 2017). Therefore, this report described a case of intracranial epidermoid cyst in a cat.

A 6-year-old mixed-breed male cat was admitted to the Hospital Veterinário Universitário of the Universidade Federal de Santa Maria, Rio Grande do Sul, Brazil, with a history of progressive lack of balance for 2 years. The owner noticed recent falls to the left. On neurologic examination, mild leftsided head tilt, dysphonia, vertical nystagmus, falls to the left, decreased level of mentation (depressed), and vestibular ataxia were observed. No other abnormalities were noted, and complete blood count $(\mathrm{CBC})$, blood smear examination, and serum biochemical profile were unremarkable. The blood sample was negative for FeLV p27 antigen and IgG antibodies against FIV, which were measured using a commercial enzyme-linked immunosorbent assay
(ELISA) (rapid assay kit, SNAP ${ }^{\circledR}$ FIV Antibody/ FeLV Antigen Combo Test: IDEXX Laboratories, Westbrook, ME, USA). The clinical signs suggested central vestibular syndrome, with cerebellovestibular neuroanatomic localization. The differential diagnoses included infectious meningoencephalitis and neoplasia. Given the poor prognosis and because the cat belonged to a shelter with many dogs and cats, the owner requested euthanasia, and a thorough post-mortem examination was conducted immediately after death.

At necropsy, examination of the brain showed the presence of an irregular, whitish mass that protruded on the left side of the medulla oblongata (Figure 1A). No other gross abnormalities were detected. The brain and samples of several organs were fixed in $10 \%$ neutral buffered formalin. Cross sections of the brain showed that the mass occupied the

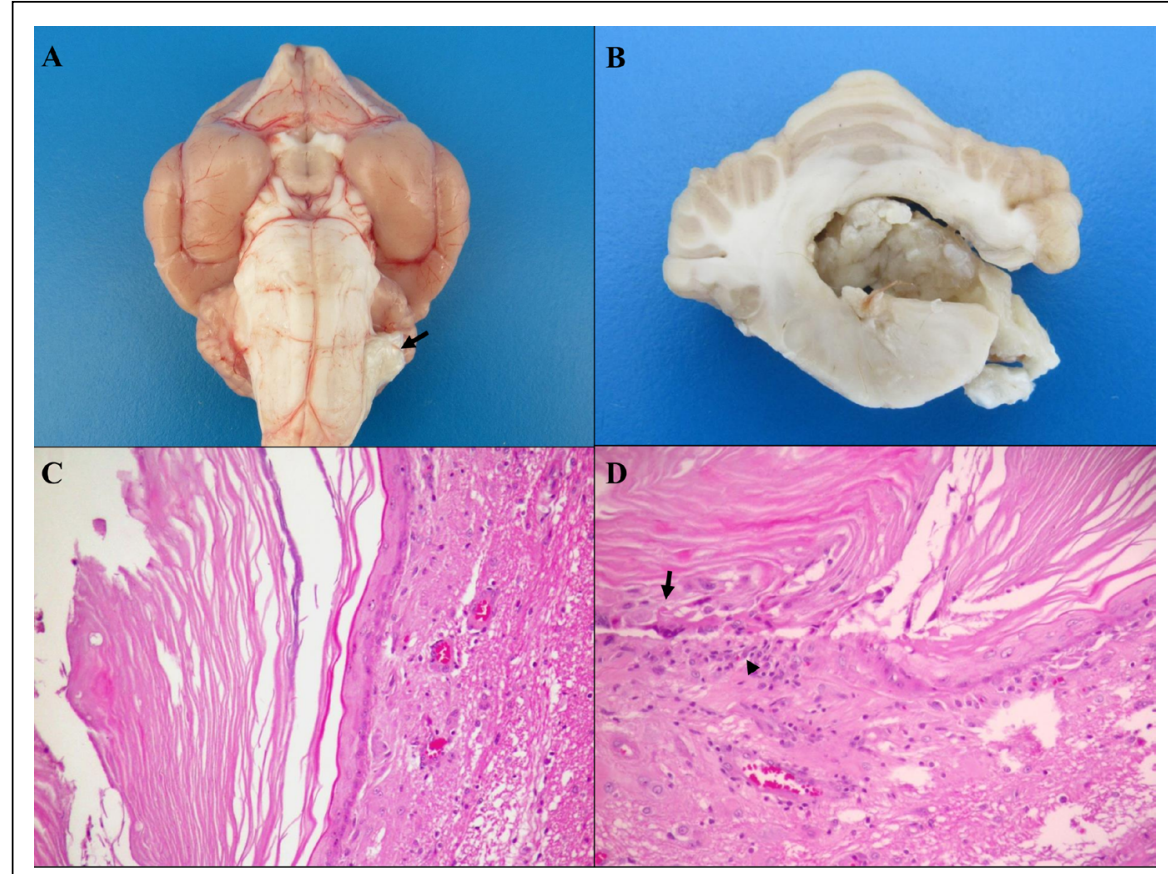

Figure 1 - A - Brain; ventral surface, epidermoid cyst; cat. Whitish mass similar to the neural tissue that arise of the medulla oblongata (arrow). B - Brain (fixation in $10 \%$ neutral buffered formalin), transverse section at the level of the cerebellar peduncles, cerebellum, and medulla oblongata; epidermoid cyst; cat. Breakable intraventricular growth, which causes marked dilation of the fourth ventricle, and compression of the cerebellar white matter. C - Brain; cerebellar medullary; epidermoid cyst; cat. Keratinizing cyst filled with desquamated concentric, and formed by squamous epithelium similar to that normally seen on the skin. HE. Obj.20×. D - Brain; cerebellar medullary; epidermoid cyst; cat. Massive granulomatous encephalitis with multinucleated giant cells (arrow), and focal gliosis (arrowhead) associated to keratin fragments. This injury is a result of the cyst rupture. HE. Obj.20×. 
fourth ventricle, was compressed and expanded into the cerebellar white matter (Figure 1B). Additionally, it destroyed the adjacent left cerebellar cortex and peduncles. Dilatations of the brain ventricles were not observed. Representative brain and other tissue samples were processed by routine methods for histology, and sections $(4 \mu \mathrm{m})$ were stained with hematoxylin and eosin (HE).

Histologically, the mass consisted of a cyst lined by a stratified squamous keratinizing epithelium filled with desquamated concentric keratin, seen as a homogeneously eosinophilic material (Figure 1C). The wall of the cyst had two or three layers of cells, and varied in thickness from one part to another. In the ruptured area of the wall, scattered fragments of keratin were present in the cerebellar white matter and were surrounded by granulomatous inflammatory reactions consisting of giant cells and an increase in the number of astrocytes and oligodendrocytes (gliosis), as a typical foreign body reaction (Figure 1D). Histopathological examination of other tissues did not reveal any changes.

In humans, an intracranial epidermoid cyst arises during the early stages of embryonic development between the 3rd and 5th week of gestation. However, regarding domestic animals, this specific information is not found in the veterinary literature, but possibly corresponds to the neural tube formation period, between the 3rd and 4th week of gestation (SMIRNIOTOPOULOS \& CHIECHI, 1995; NAGASAWA et al., 2011). Additionally, in human medical literature, there are few descriptions of intracranial epidermoid cysts acquired as a result of trauma or iatrogenic implantation, but the pathogenesis in these cases has been questioned (TOGLIA et al., 1965).

Based on human literature, intracranial epidermoid cysts occur most frequently within the cerebellopontine angle, followed by the fourth ventricle, and less commonly in the sellar and parasellar regions, similar to those in the veterinary literature and in the present case, in which the fourth ventricle was affected (TOGLIA et al., 1965; KORNEGAY \& GORGACZ, 1982; NOBEL et al., 1987; PETERS et al., 2003; MACKILLOP et al., 2006; FORGANI et al., 2007; NAGASAWA et al., 2011). This anatomical predilection is probably associated with the direction of closure of the neural tube and the separation from the ectoderm during embryonic life, which occurs at the future cervical region of the embryo, proceeding in the anterior and posterior directions (MOORE \& PERSAUD, 2008; SINOWATZ, 2012).
In this case, the clinical findings indicated a central vestibular syndrome, reflecting that the majority of the lesion was located in the cerebellar medullary, as in most veterinary literature reports, in which ataxia, head tilt, decreased level of mentation, and nystagmus were the main clinical signs observed in animals with intracranial epidermoid cysts (KORNEGAY \& GORGACZ, 1982; PLATT et al., 1999; PETERS et al., 2003; MACKILLOP et al., 2006). Histologically, a dermoid cyst was included as a differential diagnosis to epidermoid cyst. Dermoid cysts consist of a cavity filled with laminated keratin mixed with hair fragments lined by stratified squamous keratinizing epithelium and collagen bundles, including hair follicles, sebaceous glands, and occasional apocrine sweat glands (GOLDSCHMIDT \& SCHOFER, 1992; GROSS et al., 2005). The absence of adnexal structures in the wall was the fundamental criterion for exclusion of dermoid cysts. To the authors' knowledge, this is the first report of an intracranial epidermoid cyst in a cat. In addition, it is important to include epidermoid cysts as a differential diagnosis in adult cats with clinical signs of central vestibular syndrome.

\section{ACKNOWLEDGMENTS}

To the Conselho Nacional de Desenvolvimento Científico e Tecnológico $(\mathrm{CNPq})$, and Coordenação de Aperfeiçoamento de Pessoal de Nível Superior (CAPES) for the financial support.

\section{AUTHORS' CONTRIBUTION}

The authors contributed to the manuscript.

DECLARATION OF CONFLICT OF
INTERESTS

The authors declare no potential conflicts of interest with respect to the research, authorship, and/or publication of this article.

\section{REFERENCES}

CANTILE, C.; YOUSSEF, S. Nervous System. In: MAXIE, M.G. Jubb, Kennedy, Palmer's Pathology of Domestic Animals, St. Louis: Elsevier, 2016. Cap.4, p.250-406.

GOLDSCHMIDT, M. H.; et al., Skin tumors of the dog and cat, New York: Pergamon Press, 1992. p.316.

GROSS, T. L. et al. Epithelial neoplasms and other tumors: follicular tumors. In: GROSS, T.L. et al. Skin diseases of the dog and cat, Iowa: Blackwell Science, 2005. Sec.II, p.607-612.

KORNEGAY, J. N; GORGACZ, E. J. Intracranial epidermoid cysts in three dogs. Veterinary Pathology, v.19, p.646-650, 1982. 
Available from: $<$ https://journals.sagepub.com/doi/pdf/10.1177/03 0098588201900608>. Accessed: Aug. 11, 2020.

LLOYD, L. C. The etiology of cysts in the skin of some families of Merino sheep in Australia. The Journal of Pathology and Bacteriology, v.88, p.219-227, 1964. Available from: <https:// onlinelibrary.wiley.com/doi/abs/10.1002/path.1700880128>. Accessed: Aug. 11, 2020.

MACKILLOP, E. et al. A. Intracranial epidermoid cyst and syringohydromyelia in a dog. Veterinary Radiology \& Ultrasound, v.47, p.339-344, 2006. Available from: <https:// onlinelibrary.wiley.com/doi/full/10.1111/j.1740-8261.2006.00150. x>. Accessed: Aug. 11, 2020.

MOORE, K. L.; PERSAUD, T. V. N. Terceira semana do desenvolvimento humano. In: MOORE, K. L.; PERSAUD, T. V. N. Embriologia básica, Rio de Janeiro: Elsevier, 2008. Cap.5, p. $37-50$.

MILLI, U. H; HAZIROGLU, R. Pulmonary epidermoid cysts in a cat. Veterinary Record, v.127, p.287, 1990. Available from: $<$ https://www.cabdirect.org/cabdirect/abstract/19902213158>. Accessed: Sep. 23, 2020.

NAGASAWA, D. et al. Clinical characteristics and diagnostic imaging of epidermoid tumors. Journal of Clinical Neuroscience, v.18, p.1158-1162, 2011. Available from: $\quad<$ https://www.sciencedirect.com/science/article/pii/ S0967586811001263?via\%3Dihub>. Accessed: Aug. 11, 2020.

NIEDERHÄUSER, S. et al. Intestinal epidermoid cyst in a cat. Schweiz Arch Tierheilkd, v.157, p.559-562, 2015. Available from: <https://sat.gstsvs.ch/de/sat/sat-artikel/ archiv/2015/102015/intestinal-epidermoid-cyst-in-a-cat.html>. Accessed: Sep. 23, 2020.

PETERS, M. et al. Intracranial epidermoid cyst in a horse. Journal of Comparative Pathology, v.129, p.89-92, 2003. Available from: <https://www.sciencedirect.com/science/article/pii/ S002199750200169X?via\%3Dihub>. Accessed: Aug. 11, 2020.

SILVA, B. R. S. A. et al. Upper airway obstruction secondary to laryngeal epidermoid cyst in cat: case report. Brazilian Journal of Veterinary Medicine, v.39, p.74-81, 2017. Available from: $<$ https://pdfs.semanticscholar.org/b38f/1e06c90bcc99c1d2afd9de 27173681f925ce.pdf $>$. Accessed: Sep. 23, 2020.

SINOWATZ, F. Neurulação. In: HYTTEL, P.; SINOWARTZ, F.; VEJLSTED, M. Embriologia Veterinária, Rio de Janeiro: Elsevier, 2012. Cap.8, p.95-103.

SMIRNIOTOPOUlOS, J. G.; CHIECHI, M. V. Teratomas, dermoids, and epidermoids of the head and neck. Radiographics, v.15, p.1499-1502, 1995. Available from: <https://pubs.rsna. org/doi/pdf/10.1148/radiographics.15.6.8577967>. Accessed: Aug. 11, 2020.

SUGIMOTO, T. et al. An intracranial epidermal cyst in a SpragueDawley rat. The Journal of Veterinary Medical Science, v.56, p.577-579, 1994. Available from: <https://pubmed.ncbi.nlm.nih. gov/7948397/>. Accessed: Aug. 11, 2020.

TOGLIA, J. U.; et al., Epithelial (epidermoid) tumors of the cranium: their common nature and pathogenesis. Journal of Neurosurgery, v.23, p.384-393, 1965. Available from: <https:// thejns.org/view/journals/j-neurosurg/23/4/article-p384.xml>. Accessed: Aug. 11, 2020. 